Nurul Islamy: Analisis Sektor Potensial, Dapatkah Pariwisata Menjadi Lokomotif Baru

Ekonomi Nusa Tenggara Barat?

\title{
ANALISIS SEKTOR POTENSIAL, DAPATKAH PARIWISATA MENJADI LOKOMOTIF BARU EKONOMI NUSA TENGGARA BARAT?
}

\author{
Nurul Islamy \\ Fungsional Statistisi Ahli Badan Pusat Statistik Provinsi Nusa Tenggara Barat \\ nurul.islamy@bps.go.id
}

\begin{abstract}
ABSTRAK
Ekonomi Nusa Tenggara Barat (NTB) yang tercermin dalam Produk Domestik Regional Bruto (PDRB) masih tergantung pada tambang bijih logam dan ekspor. Padahal, NTB dengan berbagai keindahan alam maupun budaya lokalnya merupakan salah satu provinsi yang dalam perkembangannya ditargetkan menjadi gerbang pariwisata nasional. Dengan semakin mantapnya posisi NTB sebagai destinasi wisata nasional, sekaligus tujuan investasi di bidang kepariwisataan di Indonesia, maka perlu dilakukan studi untuk dapat diketahui sejauh mana lapangan usaha yang berafiliasi dengan dunia pariwisata memberikan kontribusi sebagai lokomotif baru perekonomian NTB di luar sektor pertambangan. Untuk mendapatkan sektor/kategori unggulan di suatu wilayah, beberapa metode pengukuran yang umum digunakan antara lain Location Quotient (LQ), Analisis Shift-Share, dan Tipologi Klassen. Berdasarkan tiga metode tersebut diperoleh hasil bahwa dari delapan kategori unggulan, tiga diantaranya merupakan kategori yang menyokong pariwisata di NTB yakni lapangan usaha Transportasi dan Pergudangan, Real Estate dan Jasa-jasa. Kategori penting lainnya yaitu Penyediaan Akomodasi dan Makan Minum; Konstruksi; dan Perdagangan berpotensi lebih digenjot untuk semakin meningkatkan perekonomian NTB. Bagi pengusaha, kategori unggulan yang menyokong pariwisata tersebut dapat "dilirik" untuk investasi di masa mendatang. Tanpa menutup kemungkinan untuk membuka usaha baru di lapangan usaha yang potensial. Ada satu kekuatan ekonomi baru yang menyeruak dari hasil analisis yaitu ekonomi kreatif. Ternyata lapangan usaha yang berkaitan dengan Ekonomi Kreatif telah terdeteksi sebagai kategori potensial yang patut dikembangan di NTB. Diperlukan kajian lebih lanjut terkait topik ini dengan menggunakan Tabel Input-Output agar didapatkan gambaran hubungan timbal balik dan keterkaitan antarsektor dalam perekonomian di NTB secara menyeluruh utamanya terkait pariwisata.
\end{abstract}

Kata Kunci : Analisis Shift-Share, Ekonomi Kreatif, Location Quotient (LQ), Sektor Unggulan, Sektor Pariwisata, PDRB, Tipologi Klassen

\section{POTENTIAL SECTOR ANALYSIS, CAN THE TOURISM BE A NEW LOCOMOTIVE ECONOMY OF WEST NUSA TENGGARA?}

\section{ABSTRACT}

The economy of Nusa Tenggara Barat (NTB) reflected in the Gross Regional Domestic Product (GRDP) still depends on metal ore mining and exports. In fact, NTB with a variety of natural beauty and local culture is one of the provinces which in its development is targeted to become the gate of national tourism. With the increasing position of NTB as a national tourist destination, as well as an investment destination in the field of tourism in Indonesia, it is necessary to study to find out the extent to which industry affiliated with the tourism contribute as a new locomotive for the NTB economy outside the mining sector. To obtain 
leading sectors /categories in a region, several commonly used measurement methods include Location Quotient (LQ), Shift-Share Analysis, and Klassen Typology. Based on the three methods, the results show that of the eight leading categories, three of them are categories that support tourism in NTB, namely the Transportation and Storage, Real Estate and Services. Other important categories are Accomodation \& food Service Activities; Construction; and Trade has the potential to be further boosted to further improve the NTB economy. For entrepreneurs, the leading categories that support tourism can be "glimpsed" for investment in the future. Without closing the possibility to open a new business in a potential industry. There is one new economic power that has emerged from the results of analysis, namely the creative economy. It turns out that the industry related to the Creative Economy have been detected as potential categories that deserve to be developed in NTB. Further studies are needed regarding this topic using the Input-Output Table in order to obtain an overview of the interrelationships and inter-sectoral linkages in the economy in NTB as a whole, especially related to tourism.

Keywords: Creative Economy, GRDP, Klassen Typology, Leading Sector, Location Quotient (LQ), Shift - Share Analysis, Tourism Sector.

\section{PENDAHULUAN}

Sampai saat ini, ekonomi Nusa Tenggara Barat (NTB) masih tergantung pada tambang bijih logam dan ekspor luar negeri. Pada kuartal I-2018, data Badan Pusat Statistik (BPS) menunjukkan bahwa ekonomi Provinsi NTB mengalami kontraksi $-0,33$ persen dibanding periode yang sama tahun 2017 (y on y) dengan kontraksi tertinggi terjadi pada Lapangan Usaha Pertambangan dan Penggalian sebesar 20,29 persen. Hal ini juga terlihat dari sisi PDRB Pengeluaran dimana Komponen Ekspor Luar Negeri mengalami kontraksi paling tinggi yaitu $-22,46$ persen.

Meskipun demikian, di luar pertambangan, pertumbuhan ekonomi NTB tercatat sebesar 4,34 persen pada kuartal I2018 (y on y). Petumbuhan tertinggi dicatatkan oleh kategori Jasa Keuangan sebesar 11,61 persen. Kategori penyediaan akomodasi dan makan minum sebagai bagian dari sektor pariwisata berada pada posisi kedua dengan pertumbuhan tertinggi yakni sebesar 10,99 persen, dan posisi ketiga diduduki oleh kategori real estate sebesar 7,07 persen.

Menurut Sukirno (2011) pertumbuhan ekonomi merupakan suatu ukuran kuantitatif yang menggambarkan perkembangan suatu perekonomian dalam suatu tahun tertentu apabila dibandingkan dengan tahun sebelumnya. Dengan melihat pertumbuhan ekonomi daerahnya, pemerintah daerah akan bisa membandingkan kecepatan pembangunan dari setiap sektor yang ada.

Provinsi Nusa Tenggara Barat (NTB) merupakan salah satu provinsi di Indonesia yang dalam perkembangannya ditargetkan menjadi gerbang pariwisata nasional bersama provinsi lain di wilayah Nusa Tenggara. Berbagai keindahan alam maupun budaya lokal menjadi daya tarik wisata. NTB dengan "Pesona Lombok Sumbawa"nya menawarkan sejumlah destinasi wisata yang tidak kalah menarik dari tetangga sebelah, Bali. Apalagi empat dari sepuluh destinasi "Bali Baru" yang ditetapkan Kementerian Pariwisata berada di NTB. Hal ini membuat sektor pariwisata di NTB mulai banyak dilirik oleh investor.

Dengan semakin mantapnya posisi NTB sebagai destinasi wisata nasional, sekaligus tujuan investasi di bidang kepariwisataan di Indonesia, maka perlu dilakukan studi untuk dapat diketahui sejauh mana lapangan usaha yang berafiliasi dengan dunia pariwisata memberikan kontribusi.

Sebagai lokomotif baru perekonomian NTB di luar sektor pertambangan sehingga 
dapat menjadi dasar pembentukan kebijakan yang lebih optimal dalam mengembangkan potensi di bidang pariwisata.

\section{LANDASAN TEORI}

Selain memiliki kawasan-kawasan strategis pariwisata di Lombok dan Sumbawa yang cocok sebagai lokasi pembangunan kepariwisataan dan layak dikembangkan para investor, sejumlah kemudahan investasi dari sisi perizinan di NTB juga menjadi salah satu faktor. Hal ini sejalan dengan yang disebutkan oleh Berli (2014) dalam penelitiannya.

Perkembangan pariwisata sudah sepatutnya mendapat perhatian bagi pemerintah selaku pengatur daerah. Seperti yang diungkap Yoeti (2008) bahwa jika pemerintah tidak mengerti serta tidak mendukung perkembangan pariwisata, maka perekonomian secara keseluruhan akan menderita, karena akan banyaknya sarana perekonomian yang akan terbengkalai atau menganggur. Pembangunan kepariwisataan sejatinya diarahkan agar kegiatan pariwisata menjadi salah satu sektor basis/andalan perekonomian yang mampu menggerakkan sektor-sektor ekonomi lain guna menyediakan lapangan pekerjaan, meningkatkan pendapatan masyarakat, dan perolehan devisa. Karena setiap perubahan yang terjadi pada sektor basis akan menimbulkan efek ganda (multiplier effect) dalam perekonomian regional (Adisasmita, 2005).

\section{METODE}

Jenis penelitian ini adalah penelitian kuantitatif. Martono (2010) mendefinisikan penelitian kuantitatif sebagai penelitian yang dilakukan dengan menggunakan data berupa angka. Data yang digunakan dalam penelitian ini adalah data sekunder berupa Produk Domestik Regional Bruto (PDRB) Provinsi NTB Tahun 2013-2017. Pertumbuhan PDRB dari waktu ke waktu akan mencerminkan pemanfaatan dan daya saing potensi ekonomi dari suatu wilayah. Sementara itu, untuk mendapatkan sektor/kategori unggulan di suatu wilayah, beberapa metode pengukuran yang umum digunakan antara lain Location Quotient (LQ), Analisis Shift-Share, dan Tipologi Klassen (Amalia, 2012).

\section{Location Quotient (LQ)}

Analisis LQ digunakan untuk menunjukkan besarnya peranan sektor perekonomian suatu wilayah dengan membandingkan sektor yang sama pada wilayah yang lebih besar. Metode ini digunakan untuk mengidentifikasi sektor ekonomi potensial yang menjadi unggulan dan dapat dikembangkan di suatu wilayah. Disamping itu juga digunakan untuk mengidentifikasi keunggulan komparatif (comparative advantage) suatu wilayah.

$$
L Q_{i}=\frac{P D R B_{i j}}{P D R B_{j}} / \frac{P D B_{i}}{P D B}
$$

a. Jika LQ $>1$, sektor i di wilayah analisis $\mathrm{j}$ merupakan sektor unggulan, yaitu sektor yang tingkat spesialisasinya lebih tinggi pada wilayah analisis tersebut daripada tingkat wilayah yang lebih luas lagi (wilayah referensi).

b. Jika $L Q=1$, sektor i di wilayah analisis $\mathrm{j}$ bukan merupakan sektor unggulan, yaitu sektor yang tingkat spesialisasinya sama dengan wilayah referensi.

c. Jika LQ $<1$, sektor i di wilayah analisis $\mathrm{j}$ bukan merupakan sektor unggulan, yaitu sektor yang tingkat spesialisasinya lebih rendah daripada wilayah referensi.

Dimana Provinsi NTB sebagai wilayah analisis dan wilayah referensinya adalah Indonesia.

\section{Analisis Shift-Share}

Analisis shift share merupakan salah satu teknik untuk menganalisis data statistik regional, seperti PDRB, tenaga kerja dan lain-lain untuk mengamati struktur perekonomian daerah dan perubahannya 
secara deskriptif. Caranya dengan menitikberatkan pada pertumbuhan sektor di suatu wilayah dan memproyeksikan kegiatan ekonomi di wilayah tersebut dengan data yang terbatas (Firdaus, 2007). Analisis ini merupakan salah satu teknik kuantitatif yang biasa digunakan untuk menganalisis perubahan struktur ekonomi suatu wilayah terhadap struktur ekonomi wilayah administratif yang lebih luas sebagai referensi.

Dalam metode ini terdapat 3 bagian yaitu:

a. Regional Share (RS) merupakan komponen share pertumbuhan ekonomi daerah yang disebabkan oleh faktor eksternal. RS mengindikasikan adanya peningkatan kegiatan ekonomi daerah akibat kebijakan nasional yang berlaku.

b. Proporsional Shift (PS) komponen pertumbuhan ekonomi daerah yang disebabkan oleh struktur ekonomi daerah tersebut yang baik, dengan berspesialisasi pada sektor yang pertumbuhannya cepat.

c. Differential Shift (DS) merupakan komponen pertumbuhan ekonomi daerah karena kondisi spesifik daerah yang kompetitif. Unsur pertumbuhan ini merupakan keunggulan kompetitif daerah yang dapat mendorong pertumbuhan ekspor daerah

d. Shift Share (SS) merupakan penjumlahan dari Regional Share dengan Proportional Share dan Differential Share

$$
\begin{gathered}
R S i j=P D R B_{i j} x r_{n} \\
P S i j=P D R B_{i j} x\left(r_{i n}-r_{n}\right) \\
D S i j=P D R B_{i j} x\left(r_{i j}-r_{i n}\right) \\
S S i j=R S i j+P S i j+D S i j
\end{gathered}
$$

a. Jika PSij $>0$, artinya bahwa sektor $\mathrm{i}$ pada suatu wilayah analisis tumbuh lebih cepat daripada sektor i di wilayah referensi, dan sebaliknya.

b. Jika DSij > 0, artinya bahwa daya saing sektor i pada suatu wilayah analisis lebih tinggi dari daya saing sektor i di wilayah referensi, dan sebaliknya.

c. Jika $\mathrm{SSij}>0$, artinya terjadi penambahan nilai absolut atau mengalami kenaikan kinerja ekonomi daerah pada sektor i di wilayah analisis tersebut.

Dari ukuran diatas, maka sektor unggulan wilayah adalah sektor-sektor yang mempunyai daya saing yang tinggi. Daya saing suatu sektor menunjukkan potensi yang tinggi untuk dikembangkan.

\section{Tipologi Klassen}

Tipologi Klassen mendasarkan pengelompokkan suatu sektor di suatu wilayah dengan cara membandingkan pertumbuhan ekonomi wilayah tersebut dengan pertumbuhan ekonomi wilayah yang lebih luas dan membandingkan pangsa sektor tersebut dengan nilai rata-ratanya di tingkat yang lebih luas. Hasil analisis Tipologi Klassen akan menunjukkan posisi pertumbuhan dan pangsa sektor tersebut dalam membentuk perekonomian di suatu wilayah.

Untuk melihat potensi ekonomi di suatu wilayah digunakan pendekatan pertumbuhan sektoral dan kontribusinya terhadap perekonomian di suatu wilayah. Melalui metode ini diperoleh empat karakteristik pola dan struktur pertumbuhan dari sektor ekonomi yang berbeda, yaitu: sektor unggulan dan tumbuh pesat, sektor unggulan tapi pertumbuhannya tertekan, sektor potensial yang berkembang cepat, dan sektor

\begin{tabular}{|c|c|c|}
\hline \multirow{2}{*}{$\begin{array}{l}\text { Kontribusi } \\
\text { Sektoral }\end{array}$} & \multicolumn{2}{|c|}{ Pertumbuhan Sektoral } \\
\hline & $G_{i} \geq G$ & $G_{i}<G$ \\
\hline$S_{i} \geq S$ & $\begin{array}{l}\text { Sektor } \\
\text { unggulan dan } \\
\text { tumbuh pesat }\end{array}$ & $\begin{array}{l}\text { Sektor unggulan } \\
\text { tapi } \\
\text { pertumbuhannya } \\
\text { tertekan }\end{array}$ \\
\hline$S_{i}<S$ & $\begin{array}{l}\text { Sektor } \\
\text { potensial dan } \\
\text { masih dapat }\end{array}$ & $\begin{array}{lr}\text { Bukan } & \text { sektor } \\
\text { potensial } & \text { dan } \\
\text { tertinggal } & \end{array}$ \\
\hline
\end{tabular}
yang tidak potensial.

Tabel 1. Kategori Sektor Berdasarkan Tipologi Klassen 
Nurul Islamy: Analisis Sektor Potensial, Dapatkah Pariwisata Menjadi Lokomotif Baru Ekonomi Nusa Tenggara Barat?

\begin{tabular}{lll}
\hline Kontribusi & \multicolumn{2}{c}{ Pertumbuhan Sektoral } \\
\cline { 2 - 3 } Sektoral & $G_{i} \geq G$ & $G_{i}<G$ \\
\hline & dikembangkan
\end{tabular}

$\mathrm{G}_{\mathrm{i}}$ :Pertumbuhan sektor i di wilayah analisis G: Pertumbuhan sektor i di wilayah referensi $\mathrm{S}_{\mathrm{i}}$ : Kontribusi sektor i di wilayah analisis S: Kontribusi sektor i di wilayah referensi Dalam penentuan sektor unggulan digunakan aturan sebagai berikut:

- Jika LQ positif $(+)$ dan metode lain salah satu positif $(+) \rightarrow$ Maka kategori tersebut termasuk unggulan dan potensial dari segi kontribusi atau pertumbuhan

- Jika LQ positif $(+)$ metode lain negatif $(-) \rightarrow$ Maka kategori tersebut termasuk unggulan namun kontribusi nilai tambah dan pertumbuhannya kecil

- Jika LQ negatif (-) dan metode lain ada yang positif $(+) \rightarrow$ Maka kategori tersebut termasuk potensial dari segi kontribusi atau pertumbuhan.

\section{HASIL DAN PEMBAHASAN}

Ekonomi NTB yang diukur dari PDRB selama tahun 2013-2017 pertumbuhannya mengalami fluktuasi seperti yang ditunjukkan pada Gambar 1 di bawah. Terlihat bahwa ekonomi NTB secara keseluruhan bertumpu pada lapangan usaha Pertambangan dan Penggalian. Apabila diamati, nilai laju pertumbuhan perekonomian NTB dan pertumbuhan nilai tambah kategori pertambangan dan penggalian tidaklah jauh berbeda, dimana arah pergerakan dari laju pertumbuhan PDRB NTB selama 2013-2017 mengikuti pola laju pertumbuhan nilai tambah yang dihasilkan oleh lapangan usaha tersebut. Naik turunnya pertumbuhan perekonomian NTB sejalan dengan pertumbuhan nilai tambah yang dihasilkan oleh kategori pertambangan dan penggalian. Hal ini menggambarkan betapa besar pengaruh nilai tambah kategori pertambangan dan penggalian terhadap perekonomian NTB.
Ekonomi NTB harus mulai beranjak dari tambang yang notabene merupakan unrenewable resources, tetapi beralih pada ekonomi yang suistanable berbasis ekonomi kreatif yang dapat memberikan kesejahteraan kepada seluruh masyarakat NTB. Sejatinya, pariwisata dapat menjadi garda utama perekonomian di NTB dari sektor nontambang. Dengan semua modal utama yang dimiliki serta garansi keamanan yang menjamin kepariwisataan, maka bukan tidak mungkin jika ekonomi NTB ke depannya digerakkan dari tingginya geliat perputaran keuangan di dunia pariwisata. Ekonomi NTB tidak lagi bergantung pada tambang yang notabene merupakan unrenewable resources, tetapi beralih pada ekonomi yang suistanable berbasis ekonomi kreatif yang dapat memberikan kesejahteraan kepada seluruh masyarakat NTB.

Berbagai program pengembangan pariwisata, mulai dari regulasi, promosi, hingga penguatan destinasi memberikan fakta yang tidak dapat dibantah yakni tingkat kunjungan wisatawan ke NTB terus mengalami peningkatan yang sangat signifikan dari tahun ke tahun. Hal ini terbukti sejak 2009 hingga 2017 jumlah kedatangan wisatawan meningkat 20-40 persen setiap tahunnya.

Badan Pusat Statistik (BPS) Provinsi NTB memperkirakan untuk periode 2016 saja, jumlah tamu yang menginap baik di hotel bintang maupun nonbintang sebanyak 2,1 juta orang. Masing-masing 1,5 juta wisatawan domestik dan 600 ribu wisatawan asing. Pencapaian tersebut meningkat hampir 103 persen jika dibandingkan dengan tahun sebelumnya. Selain itu, ada suatu kebanggaan tersendiri bahwa beberapa tahun ke belakang ini, Provinsi NTB juga banyak mendapatkan penghargaan dalam kepariwisataan diantaranya predikat Muslim Friendly Destination atau Best Halal Destination yang datang dari pengakuan dunia. Melihat begitu pesatnya perkembangan sektor ini maka tidak salah jika sektor pariwisata digadang-gadang akan 
menjadi salah satu sektor andalan baru NTB. penggerak lokomotif pertumbuhan ekonomi

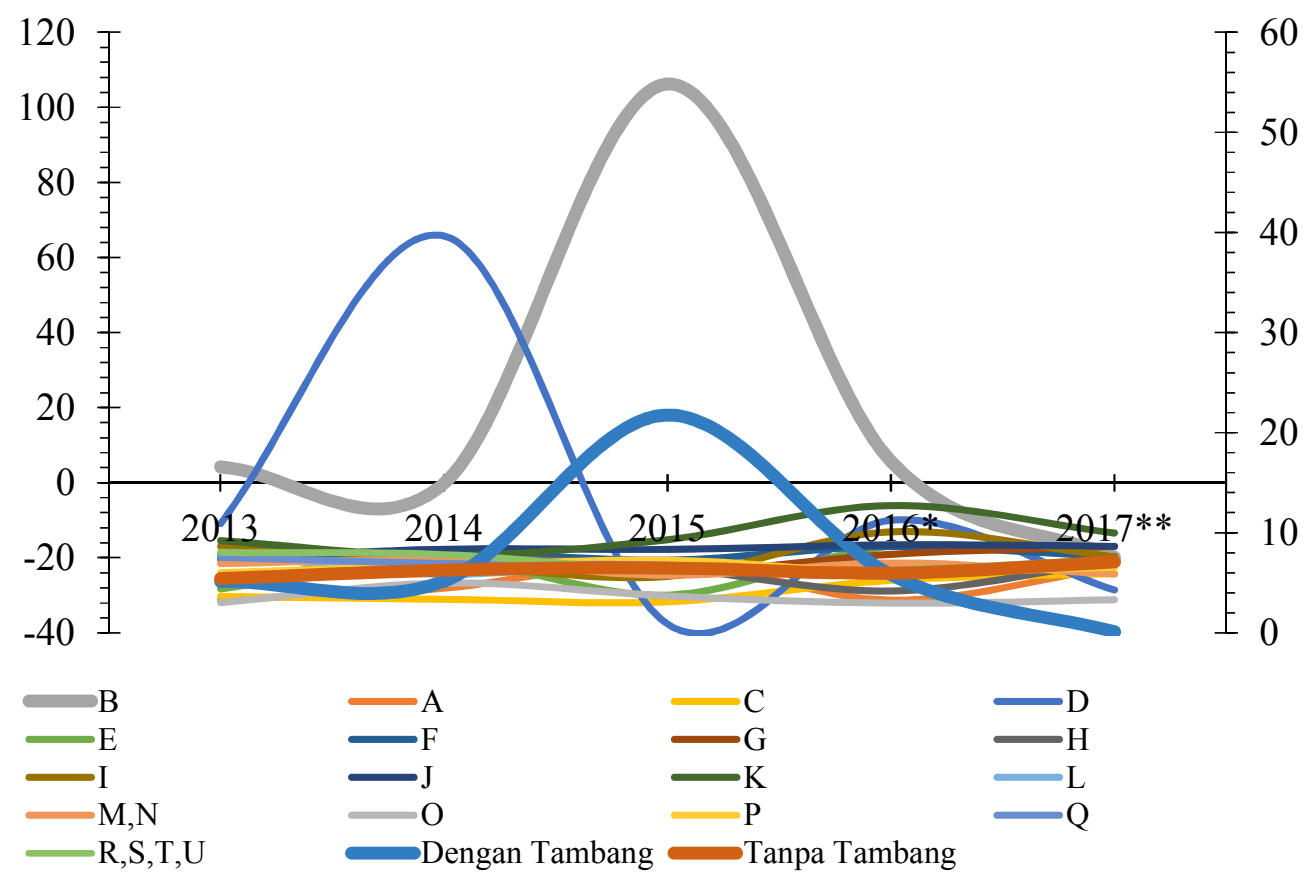

Gambar 1

Perkembangan Laju Pertumbuhan PDRB Provinsi NTB Menurut Lapangan Usaha

Ket: *Angka Sementara

**Angka Sangat Sementara

Hasil penghitungan shift share sebagaimana tersaji pada tabel di bawah. Berdasarkan tabel shift share tersebut untuk Proportional Shift (PSij) dimana merujuk pada PSij yang bernilai positif, sebanyak 12 kategori PDRB Provinsi NTB berspesialisasi dengan kategori yang tumbuh cepat pada perekonomian Nasional (Fachrurrazy, 2009). Secara umum komposisi pertumbuhan kategori pada perekonomian Nasional memperlambat pertumbuhan PDRB Provinsi NTB sekitar 5,16 Triliun Rupiah. Hal tersebut sebagian besar disebabkan melambatnya kategori pertambangan dan penggalian di tingkat Nasional dan Provinsi NTB pada periode 2013-2017, sementara kategori tersebut memiliki share cukup besar bagi perekonomian Provinsi NTB.

Differential Shift (Dsij) menunjukkan terdapat 10 (sepuluh) kategori PDRB Provinsi NTB yang bernilai positif yaitu A,
D, E, F, G, I, K, L, P dan R,S,T,U. Kategori-kategori tersebut memiliki keunggulan kompetitif dibandingkan dengan kategori yang sama secara rata-rata nasional. Keunggulan komparatif pada umumnya disebabkan faktor sumber daya alam dan manusia yang memadai serta kebijakan pemerintah yang mendukung pertumbuhan kategori-kategori tersebut (Wahyufitri, 2007).

Sementara itu, rata-rata LQ Provinsi NTB tahun 2013-2017 menunjukkan terdapat 8 kategori yang bernilai lebih dari 1 . Hal yang menarik adalah kategori I yang berkaitan erat dengan pariwisata memiliki LQ di bawah 1, berarti kategori ini masih belum mampu menjadi aktivitas basis tetapi potensial dari segi kontribusi dan pertumbuhan. Kemudian, untuk kategori $\mathrm{H}$ dan Q meskipun dari hasil LQ merupakan aktivitas basis dan mampu mendorong 
perekonomian Provinsi NTB, namun mempertimbangkan hasil analisis shift share kedua kategori ini kurang memiliki keunggulan komparatif dalam perekonomian Nasional. Sementara kategori A, walaupun memiliki share tertinggi dalam PDRB Provinsi NTB, namun mengalami perlambatan dalam perekonomian Nasional. Hal tersebut mencerminkan kebijakan pertumbuhan positif aktivitas pertanian, kehutanan dan perikanan dalam periode 2013-2017.

Berdasarkan analisis dengan tiga metode di atas diperoleh hasil sebagaimana yang ditunjukkan pada Tabel 2. Dari delapan kategori unggulan, tiga diantaranya merupakan kategori yang menyokong pariwisata di NTB yakni lapangan usaha Transportasi dan Pergudangan, Real Estatet dan Jasa-jasa. Kategori penting lainnya yaitu Penyediaan Akomodasi dan Makan Minum; Konstruksi; dan Perdagangan berpotensi lebih digenjot untuk semakin meningkatkan perekonomian NTB. Bagi pengusaha, kategori unggulan di yang "dilirik" untuk investasi di masa mendatang. Tanpa menutup kemungkinan untuk membuka usaha baru di lapangan usaha yang potensial. Pemerintah belum mampu mendorong menyokong pariwisata tersebut dapat

Lapangan usaha Pertambangan dan Penggalian berdasarkan Tabel 2 memang merupakan salah satu kategori unggulan penopang ekonomi NTB. Akan tetapi, kategori ini berperilaku fluktuatif dan pada tahun penelitian pertumbuhannya tertekan. Dalam artian, jika nilai tambah produksi kategori pertambangan dan penggalian sedang tinggi maka akan menanjak peranannya terhadap perekonomian NTB, sedangkan peranan kategori lainnya menjadi tertekan menurun dibandingkan tahun sebelumnya. Sebaliknya, apabila nilai tambah produksi kategori pertambangan dan penggalian sedang menurun berakibat pada turunnya peranan kategori pertambangan dan penggalian terhadap perekonomian secara signifikan, yang diiringi dengan melonjaknya peranan kategori selain pertambangan dan penggalian terhadap perekonomian NTB. Ini memperlihatkan daerah ini belum mengoptimalkan sektor di luar non-renewable. Kondisi ini kental dengan keadaan yang mendekatkan NTB pada kondisi "kutukan sumber daya alam" (resources course). Teori kutukan sumber daya alam yang diperkenalkan oleh Richard M. Authy pada tahun 1993 menyebutkan, negeri yang dikaruniai sumber daya alam melimpah justru menjadi bangsa yang terbelakang jika tidak berhati-hati mengelolanya (Luthfi, 2008).

Tabel 2.

\section{Ringkasan Hasil Penghitungan LQ, Analisis shift share, dan Tipologi Klassen Menurut} Lapangan Usaha PDRB Provinsi NTB

\begin{tabular}{|c|c|c|c|c|c|c|}
\hline \multirow{2}{*}{$\begin{array}{l}\text { Kateg } \\
\text { ori }\end{array}$} & \multirow{2}{*}{ Rincian } & \multirow{2}{*}{$\begin{array}{l}\mathbf{L} \\
\mathbf{Q}\end{array}$} & \multicolumn{2}{|c|}{$\begin{array}{c}\text { Shift } \\
\text { Share }\end{array}$} & \multirow{2}{*}{$\begin{array}{c}\text { Klas } \\
\text { sen }\end{array}$} & \multirow{2}{*}{ Kesimpulan } \\
\hline & & & $\begin{array}{l}\text { PS } \\
\text { ij }\end{array}$ & $\begin{array}{c}\text { DS } \\
\text { ij }\end{array}$ & & \\
\hline A & Pertanian, Kehutanan, dan Perikanan & + & - & + & $\begin{array}{c}\mathrm{KW} \\
1\end{array}$ & Unggulan \\
\hline $\mathrm{B}$ & Pertambangan dan Penggalian & + & - & - & $\begin{array}{c}\mathrm{KW} \\
2\end{array}$ & $\begin{array}{l}\text { Unggulan tapi pertumbuhannya } \\
\text { tertekan }\end{array}$ \\
\hline $\mathrm{C}$ & Industri Pengolahan & - & - & - & $\begin{array}{c}\mathrm{KW} \\
3 \\
\end{array}$ & Masih dapat dikembangkan \\
\hline $\mathrm{D}$ & Pengadaan Listrik dan Gas & - & - & + & $\begin{array}{c}\mathrm{KW} \\
3\end{array}$ & Potensial dari segi pertumbuhan \\
\hline $\mathrm{E}$ & $\begin{array}{l}\text { Pengadaan Air, Pengelolaan Sampah, } \\
\text { Limbah dan Daur Ulang }\end{array}$ & + & - & + & $\begin{array}{c}\text { KW } \\
1 \\
\end{array}$ & Unggulan \\
\hline $\mathrm{F}$ & Konstruksi & - & + & + & $\begin{array}{c}\mathrm{KW} \\
3\end{array}$ & Potensial dari segi pertumbuhan \\
\hline
\end{tabular}


Journal of Indonesian Tourism, Hospitality and Recreation --- Volume 2, No. 1, April 2019

eISSN: 2654-4687 ----- pISSN: 2654-3893

\begin{tabular}{|c|c|c|c|c|c|c|}
\hline \multirow{2}{*}{$\begin{array}{c}\text { Kateg } \\
\text { ori }\end{array}$} & \multirow{2}{*}{ Rincian } & \multirow{2}{*}{$\begin{array}{l}\mathbf{L} \\
\mathbf{Q}\end{array}$} & \multicolumn{2}{|c|}{$\begin{array}{l}\text { Shift } \\
\text { Share }\end{array}$} & \multirow{2}{*}{$\begin{array}{c}\text { Klas } \\
\text { sen }\end{array}$} & \multirow{2}{*}{ Kesimpulan } \\
\hline & & & PS & DS & & \\
\hline G & Perdagangan & - & - & + & $\begin{array}{c}\mathrm{KW} \\
3\end{array}$ & Potensial dari segi kontribusi \\
\hline $\mathrm{H}$ & Transportasi dan Pergudangan & + & + & - & $\begin{array}{c}\mathrm{KW} \\
2\end{array}$ & Unggulan \\
\hline I & $\begin{array}{l}\text { Penyediaan Akomodasi dan Makan } \\
\text { Minum }\end{array}$ & - & + & + & $\begin{array}{c}\mathrm{KW} \\
3\end{array}$ & $\begin{array}{l}\text { Potensial dari segi kontribusi } \\
\text { dan pertumbuhan }\end{array}$ \\
\hline $\mathrm{J}$ & Informasi dan Komunikasi & - & + & - & $\begin{array}{c}\mathrm{KW} \\
4\end{array}$ & Potensial dari segi kontribusi \\
\hline K & Jasa Keuangan & - & + & + & $\begin{array}{c}\mathrm{KW} \\
3 \\
\end{array}$ & $\begin{array}{l}\text { Potensial dari segi kontribusi } \\
\text { dan pertumbuhan }\end{array}$ \\
\hline $\mathrm{L}$ & Real Estate & + & + & + & $\begin{array}{c}\mathrm{KW} \\
1\end{array}$ & Unggulan \\
\hline $\mathrm{M}, \mathrm{N}$ & Jasa Perusahaan & - & + & - & $\begin{array}{c}\mathrm{KW} \\
4\end{array}$ & Potensial dari segi kontribusi \\
\hline $\mathrm{P}$ & Jasa Pendidikan & + & + & + & $\begin{array}{c}\mathrm{KW} \\
1\end{array}$ & Unggulan \\
\hline Q & Jasa Kesehatan dan Kegiatan Sosial & + & + & - & $\begin{array}{c}\mathrm{KW} \\
3\end{array}$ & Unggulan \\
\hline $\begin{array}{c}\mathrm{R}, \mathrm{S}, \mathrm{T}, \\
\mathrm{U}\end{array}$ & Jasa Lainnya & + & + & + & $\begin{array}{c}\mathrm{KW} \\
2\end{array}$ & Unggulan \\
\hline
\end{tabular}

Catatan:

LQ, $\mathrm{PSij}>0, \mathrm{DSij}>0$ : beri tanda positif $(+)$

LQ, $\mathrm{PSij}<0, \mathrm{DSij}<0$ : beri tanda negatif $(-)$

Ada satu kekuatan ekonomi baru yang menyeruak dari hasil di atas yaitu ekonomi kreatif. Ekonomi kreatif adalah gagasan baru sistem ekonomi yang menempatkan informasi dan kreativitas manusia sebagai faktor produksi yang paling utama (Sari, 2018). Perkembangan ekonomi kreatif di Indonesia didukung oleh arahan Presiden RI bahwa ekonomi kreatif harus menjadi tulang punggung ekonomi Indonesia dan mampu meningkatkan daya saing pariwisata Indonesia.

Ekonomi kreatif mencakup lapangan usaha Industri Pengolahan (C); Perdagangan (G); Penyediaan Akomodasi dan makan Minum (I); Informasi dan Komunikasi (J); Aktivitas Profesional, Ilmiah dan Teknis (M); Aktifitas Penyewaan, sewa guna usaha $(\mathrm{N})$; Pendidikan (P); Kesenian Hiburan dan Rekreasi (R). Ternyata lapangan usaha yang berkaitan dengan Ekonomi Kreatif telah terdeteksi sebagai kategori potensial yang patut dikembangkan di Provinsi NTB.

Menurut Saksono (2012) keberadaan ekonomi kreatif bagian dari pariwisata diprediksi mampu memicu daya saing daerah, dimana ekonomi kreatif sebagai ide/gagasan yang diharapkan memberi nilai tambah ekonomi. Ekonomi kreatif merupakan alternatif solusi permasalahan perekonomian. Bahkan menurut Irawan (2015) berdasarkan hasil penelitiannya menyebutkan bahwa ekonomi kreatif dapat menjadi sebuah jawaban atas tantangan dalam menyejahterakan masyarakat selain itu juga ekonomi kreatif dapat menurunkan tingkat pengangguran. Direkomendasikan kepada Pemerintah agar segera membangun komitmen dan mengaktualisasikan ekonomi kreatif, sehingga keberadaan ekonomi kreatif dapat menstimulasi pertumbuhan ekonomi dan meningkatkan daya saing daerah dan bahkan nasional.

Indikasi-indikasi yang tergambar melalui analisis potensi terkait kategorikategori yang berafiliasi dengan sektor pariwisata di atas setidaknya dapat disikapi dengan mengambil langkah-langkah positif untuk kesejahteraan masyarakat NTB. 
Nurul Islamy: Analisis Sektor Potensial, Dapatkah Pariwisata Menjadi Lokomotif Baru Ekonomi Nusa Tenggara Barat?

\section{KESIMPULAN}

Dari pembahasan di atas, dapat disimpulkan bahwa:

1 Sektor pariwisata di Provinsi NTB dapat dijadikan sebagai sektor potensial bagi daerahnya. Masuknya sektor pariwisata ke dalam sektor potensial dikarenakan sektor ini memberikan kontribusi yang tinggi terhadap perekonomian dan sektor ini meningkat dengan cepat pertahunnya. Dari delapan kategori unggulan, kategori yang menyokong pariwisata di NTB adalah lapangan usaha Transportasi dan Pergudangan, Real Estate dan Jasa-jasa. Kategori penting lainnya yaitu Penyediaan Akomodasi dan Makan Minum; Konstruksi; dan Perdagangan berpotensi lebih digenjot untuk semakin meningkatkan perekonomian NTB.

2 Lapangan usaha pertambangan dan penggalian yang selama ini menjadi salah satu tulang punggung ekonomi NTB memang merupakan sektor unggulan tetapi pertumbuhannya tertekan dan berfluktuasi setiap tahunnya.

3 Ada satu kekuatan ekonomi baru yang menyeruak dari hasil analisis yaitu ekonomi kreatif. Ternyata lapangan usaha yang berkaitan dengan Ekonomi Kreatif telah terdeteksi sebagai kategori potensial yang patut dikembangan di NTB. Direkomendasikan kepada Pemerintah agar segera membangun komitmen dan mengaktualisasikan ekonomi kreatif, sehingga keberadaan ekonomi kreatif dapat menstimulasi pertumbuhan ekonomi dan meningkatkan daya saing daerah dan bahkan nasional.

4 Diperlukan kajian lebih lanjut terkait topik ini dengan menggunakan Tabel InputOutput agar didapatkan gambaran hubungan timbal balik dan keterkaitan antarsektor dalam perekonomian di NTB secara menyeluruh utamanya terkait pariwisata.

\section{DAFTAR PUSTAKA}

Adisasmita, Rahardjo. (2005). Dasar-Dasar Ekonomi Wilayah. Yogyakarta: Penerbit Graha Ilmu.
Amalia, Fitri. (2012). Penentuan Sektor Unggulan Perekonomian Wilayah Kabupaten Bone Bolango dengan Pendekatan Sektor Pembentuk PDRB. Jurnal Etikonomi, 11(2), hlm.196-207.

Badan Pusat Statistik RI. (2015). Pendapatan Nasional Indonesia 20132017. Jakarta: Badan Pusat Statistik RI.

Badan Pusat Statistik RI. (2018). Pendapatan Nasional Indonesia 20132017. Jakarta: Badan Pusat Statistik RI.

Badan Pusat Statistik Provinsi NTB. (2015). Produk Domestik Regional Bruto Provinsi Nusa Tenggara Barat Menurut Lapangan Usaha 2010-2014. Mataram: Badan Pusat Statistik Provinsi NTB.

Badan Pusat Statistik Provinsi NTB. (2018). Produk Domestik Regional Bruto Provinsi Nusa Tenggara Barat Menurut Lapangan Usaha 2013-2017. Mataram: Badan Pusat Statistik Provinsi NTB.

Berli, Dani. (2014). Pengaturan Penanaman Modal Asing di Sektor Pariwisata Menurut TRIMs dan Implementasinya di Kabupaten Lombok Tengah. (Skripsi). Fakultas Hukum, Universitas Mataram, Mataram.

Fachrurrazy. (2009). Analisis Penentuan Sektor Unggulan Perekonomian Wilayah Kabupaten Aceh Utara Dengan Pendekatan Sektor Pembentuk $P D R B$. Pascasarjana Universitas Sumatera Utara, Medan.

Firdaus. (2007). Ekonomi Regional. Jakarta: Universitas Terbuka.

Irawan, Andri. (2015). Ekonomi Kreatif Sebagai Suatu Solusi Mensejahterakan Masyarakat dalam Meningkatkan Tingkat Perekonomian. Proceedings SNEB 2015.

Fatah, Luthfi. (2008). The Impacts of Coal Mining on the Economy and Environment of South Kalimantan Province, Indonesia. Journal ASEAN Economic Bulletin, 25(1), hlm. 85-98. 
Journal of Indonesian Tourism, Hospitality and Recreation --- Volume 2, No. 1, April 2019 eISSN: 2654-4687 ----- pISSN: 2654-3893

Martono, Nanang. (2010). Metode Penelitian Kuantitatif: Analisis Isi dan Analisis Data Sekunder. Jakarta: Rajagrafindo Persada.

Saksono, Herie. (2012). Ekonomi Kreatif: Talenta Baru Pemicu Daya Saing Daerah. Jurnal Bina Praja, 4(2), hlm. 93-104.

Sari, Novita. (2018). Pengembangan Ekonomi Kreatif Bidang Kuliner Khas Daerah Jambi. Jurnal Sains Sosio Humaniora, 2(1), hlm. 51-60.
Sukirno, Sadono. (2011). Ekonomi Pembangunan: Proses, Masalah, dan Dasar Kebijakan. Jakarta: Kencana.

Wahyufitri, Tina. (2012). Tinjauan Perekonomian Kota Bengkulu Tahun 2006-2010. Bengkulu: BPS Kota Bengkulu.

Yoeti, Oka A. (2008). Perencanaan dan Pengembangan Pariwisata. Jakarta: Pradnya Paramitha.

Todaro, Michael P. (1997). Pembangunan Ekonomi di Dunia Ketiga. Diterjemahkan oleh: Drs. Haris Munandar, MA. Jakarta: Airlangga. 